\title{
BATAS-BATAS KONSTITUSIONAL HUKUM ISLAM DALAM HUKUM NASIONAL
}

\author{
Muhammadun \\ Institut Agama Islam Bunga Bangsa Cirebon \\ Muhammadunabdillah77@gmail.com \\ Murjazin \\ UIN Sunan Kalijaga Yogyakarta \\ Ahmadmurjazin85@gmail.com
}

\begin{abstract}
Indonesia is known as a country with a mixed legal system. The legal system currently in effect is dominated by three major legal systems, namely the Western legal system, the customary law system and the Islamic legal system. The basic rules that serve as guidelines and guidelines for citizens are extracted from the value system. This value system is expressed in the form of "collective agreement". This form of collective agreement is translated into the five basic principles of having a state, namely Pancasila. Within these limitations, there are gaps in applying Islamic teachings, which are limited to their substantive value. This study wants to explain why Islamic law cannot be used as the basis of the constitution and the extent to which the limitations are allowed in applying Islamic teachings as the teachings of the majority of Indonesian citizens. In responding to the issues surrounding the application of Islamic law in Indonesia, the discussion will focus on the concept of the constitution, sources of national law, and the form of the Muslim community's strategy in an effort to apply Islamic law within the national legal framework.
\end{abstract}

Kata Kunci: Batasan Konstitusional, Hukum Islam, Hukum Positif

\section{A. Pendahuluan}

Dalam sistem ketatanegaraan, Indonesia merupakan salah satu bentuk negara bangsa yang terdiri dari wilayah teritorial dan keragaman suku, ras, budaya dan agama. Keragaman suku, budaya dan agama memerlukan aturan dasar yang menjamin hak-hak dan kepentingan warga negara dalam melakukan hubungan hukum satu sama lainnya untuk ketertiban bersama. Aturan dasar yang menjadi pedoman dan pegangan warga negara digali dari sistem nilai mengakomodir seluruh kepentingan warga negara. Sistem nilai ini dituangkan dalam bentuk "kesepakatan bersama", dalam istilah sistem tata negara modern disebut konstitusi. Konstitusi berfungsi membatasi kekuasaan agar tidak sewenang-wenang menyelenggarakan kekuasaan, sehingga terjaminnya hak-hak warga negara yang bersifat majemuk. ${ }^{1}$

Di Indonesia, bentuk kesepakatan bersama tersebut dituangkan ke dalam lima prinsip dasar berbegara yaitu pancasila. Sejarah mencatat, pancasila dijadikan dasar negara adalah hasil diskusi panjang bahkan menjadi polemik yang terjadi antara warga

\footnotetext{
${ }^{1}$ Soetanto Soepladhy, Meredesain Konstitusi, (t.tp.: Kepel Press, 2004), 23.
} 
negara Indonesia yang terdiri dari agama yang berbeda. Harus diakui, keragaman suku, budaya dan agama oleh masing-masing warga negara tidak terlepas dari adanya kepentingan untuk melaksanakan ajaran agamanya masing-masing sekaligus menjadikan agama sebagai dasar negara.

Umat Islam sebagai warga negara mayoritas mempunyai keinginan dasar negara Indonesia adalah Islam. Perjuangan umat Islam mejadikan Islam sebagai dasar negara Indonesia selalu mengalami "kegagalan". Setidaknya terdapat dua periode penting yang menandai umat Islam dalam memperjuangkan Islam sebagai dasar negara. Pertama, pada tahun 1945 dengan lahirnya UUD 1945 sebagai konstitusi negara. Saat ini umat Islam belum berhasil menjadikan Islam sebagai dasar negara, akan tetapi mendapat pengakuan menjalankan hukum Islam yang tertuang dalam piagam Jakarta. Piagam Jakarta ini dirumuskan dalam mukaddimah UUD yang disahkan oleh BPUPKI. Sejumlah kepentingan dan pertimbangan bahwa negara Indonesia bukan negara Islam, tetapi negara pancasila, maka keberadaan piagam Jakarta dalam mukaddimah tersebut dihapuskan oleh PPKI menjadi pembukaan UUD 1945 yaitu Ketuhanan Yang Maha Esa.

Kedua, pada tahun 1955-1959 dengan kemenangan pemilu umat Islam kembali memperjuangkan dasar negara melalui majelis konstituante.periode ini juga mengalami kegagalan menjadikan Islam sebagai dasar negara. Konsekuensi dari perjuangan umat Islam pada saat ini melahirkan Dekrit Presiden 5 Juli 1959 sekaligus dibubarkannya konstituante. Dengan demikian keberlakuan UUD 1945 menjadi eksis kembali sebagai konstitusi negara indonesia. ${ }^{2}$

Kegagalan umat Islam menjadikan Islam sebagai dasar negara hanya pada usaha menjadikan Islam sebagai ajaran dasar dalam konstitusi. Sementara pelaksanaan hukum Islam dalam negara pancasila justru mendapat pengakuan dan jaminan perlindungan dari konstitusi UUD NRI 1954 seperti tercantum dalam pasal 29 ayat 1. Hanya saja, penerapan hukum Islam secara hirarki terbatas pada level perundang-undangan. Secara legal-formal nilai-nilai yang terkandung dalam ajaran Islam lahirnya sejumlah peraturan perundang-undangan, bukan pada level konstitusi. Kehadiran hukum privat mengakomodasi nilai-nilai ajaran Islam, seperti Undang-Undang tentang Perkawinan Nomor 1 Tahun 1974, kompilasi hukum Islam dalam bentuk inpres Nomor 1 Tahun 1991.

Sedangkan hukum publik mengatur kepentingan orang banyak tidak dilaksanakan berdasarkan ajaran agama tertentu, melainkan mengacu pada sistem hukum nasional. Kecuali Provinsi Aceh sesuai dengan otonomi khusus yang diberikan pemerintah; salah satunya terdapat kewenangan menerapkan hukum publik Islam. Dan peradilan syariat Islam (mahkamah syar'iyah) yang diperluas kewenangan yurisdiksinya. ${ }^{3}$

Keinginan umat Islam menjadikan Islam sebagai dasar negara yang dituangkan dalam UUD 1945 adalah menjadi terbatas mengingat bentuk negara Indonesia adalah

\footnotetext{
${ }^{2}$ Ahmad Syafi'I Ma'arif, Islam dan Masalah Kenegaraan: Studi dalam Pencaturan Konstitusnte, (Jakarta: LP3ES, 1985), 176.

${ }^{3}$ Landasan yuridis pelaksanaan syariat islam di Aceh berdasarkan Undang-Undang Nomor 44 Tahun 1999 tentang Penyelenggaraan Keistimewaan aceh, Undang-Undang Nomor 18 Tahun 2001 tentang Otomoni Khusus dan Undang-Undang Nomor 11 Tahun 2006 tentang Pemerintahan Aceh, Al Yasa Abubakar, Penerapan Syariat Islam di Aceh: Upaya Penyusunan Fikih dalam Negara bangsa, (Banda Aceh: Dinas Syariat Islam Aceh, 2008), 2; Moh. Fauzi, Legislasi Pelaksanaan Syariat Islam di Provinsi Nanggroe Aceh Darussalam: Pergumulan Sosto-Politik dan Tinjauan Hukum Tata Negara, Disertasi Program Pascasarjana IAIN Ar-Raniry Banda Aceh, 2009, 15-16.
} 
negara pancasila yang berketuhanan. Dalam keterbatasan tersebut, terdapat celah menerapkan ajaran Islam, yaitu sebatas nilai substansinya saja. ${ }^{4}$ Studi ini ingin menjelaskan mengapa hukum Islam tidak bisa dijadikan dasar konstitusi dan sejauhmana batasan-batasan yang diperbolehkan dalam usaha menerapkan ajaran Islam sebagai ajaran mayoritas warga negara Indonesia. Untuk merespon persoalan di seputar pemberlakuan hukum Islam di Indonesia, pembahasan akan difokuskan pada konsep konstitusi, sumber hukum nasional, serta bentuk strategi umat Islam dalam upaya menerapkan hukum Islam dalam kerangka hukum nasional. Tujuan dari studi ini adalah memaparkan peluang konstitusionalisai hukum Islam kedalam sistem hukum nasional sesuai dengan konsep konstitusi negara-bangsa berdasarkan ideologi pancasila. Uraian selanjutnya dengan menggunakan deskriptif-analisis-responsif sesuai dengan tema sentral yang menjadi fokus bahasan studi.

\section{B. Konstitusi: Sebuah Definisi}

Asal mula kata konstitusi berasal dari bahasa prancis yaitu Constituer, artinya membentuk atau menyusun, menyatakan suatu negara. ${ }^{5}$ Sedangkan dalam bahasa inggris digunakan istilah constituation. Dalam bahasa latin, konstitusi berasal dari dua kata, yaitu cume (bersama) dan statuere (berdiri, menetapkan sesuatu). Bentuk tunggalnya constitution yaitu menetapkan sesuatu secara bersama-sama, dan constitusiones sebagai bentuk jamak bermakna segala sesuatu yang telah ditetapkan.

Dalam Kamus Besar Bahasa Indonesia, konstitusi adalah segala ketentuan dan aturan yang berhubungan dengan ketatanegaraan seperti Undang-Undang Dasar yang menjadi pedoman bagi negara dalam melaksanakan kekuasaannya. Sedangkan konstitusional merujuk pada perbuatan atau tindakan yang dilakukan oleh setiap warga negara dan penguasa yang tidak sejalan dengan prinsip dasar dalam konstitusi. Konstitusionalisme adalah sebuah paham berkenaan dengan batasan kekuasaan dan jaminan terhadap hak-hak warga negara melalui konstitusi. ${ }^{6}$ Dalam istilah teknis, konstitusionalisme adalah paham bernegara yang menekankan pada jaminan perlindungan hak asasi manusia sekaligus membatasi kekuasaan negara kepada lembaga negara untuk melindungi hak asasi manusia. ${ }^{7}$

Terdapat dua unsur utama yang harus ada dalam konstitusionalisme. Pertama, perlindungan terhadap HAM beserta penjelasan jenis-jenis HAM secara rinci dalam sebuah konstitusi. Kedua, system pemerintahan negara serta lembaga-lembaga negara yang diberi wewenang untuk melindungi HAM sesuai dengan batas-batas kekuasaan dan kewenangan yang jelas. ${ }^{8}$

Pemaknaan konstitusi dalam arti membentuk atau menyusun menunjukan bahwa definisi konstitusi yang diambil dari bahasa Perancis yang merujuk pada sebuah "proses" pembentukan dan pengakuan sebuah negara atau organisasi pemerintah. Definisi ini terlihat lebih sederhana karena makna konstitusi disini lebih menekankan pada aspek proses pembentukan, sehingga tidak diketahui siapa yang membentuk;

\footnotetext{
${ }^{4}$ Moh Mahfud MD, Membangun Politik Hukum, Menegakkan Konstitusi, (Jakarta: Raja Grafindo Persada), 284.

5 Wirjono Prokodikoro, Asas-Asas Hukum Tata Negara di Indonesia, (Jakarta: Dian Rakyat, 1989), 10; Dahlan Thaib, dkk, Teori dan Hukum Konstitusi, Cet. 9, (Jakarta: Raja Grafindo Persada, 2011), 6.

${ }^{6}$ Tim Penyusun Kamus, Kamus Besar Bahasa Indonesia, Edisi III, (Jakarta: Balai Pustaka, 1991), 521.

${ }^{7}$ Moh. Mhfud MD, Aktualisasi Hukum Islam..., 28.

${ }^{8}$ Moh. Mhfud MD, Aktualisasi Hukum Islam..., 27.
} 
individu atau masyarakat. Lebih khusus adalaah definisi konstitusi dari bahasa Latin, memfokuskan pada upaya penyusunan konstitusi dilakukan secara bersama-sama, bukan individu tertentu. Kedua definisi ini masi terlihat sederhana dan masih bersifat multi tafsir. Berbeda halnya dengan makna konstitusi yang terdapat dalam Kamus Besar Bahasa Indonesia mengarah pada istilah teknis, yaitu semua aturan yang berkaitan dengan ketatanegaraan dituangkan kedalam Undang-Undang Dasar sebagai pedoman atau petunjuk dalam menjalankan sistem pemerintahan. Kriteria konstitusi yang terdapat dalam Kamus Besar Bahasa Indonesia adalah aturan tertulis, sehingga dapat dipahami sebuah aturan dikatakan sebagai konstitusi harus memenuhi persyaratan tertulis. Konsekuensinya, setiap aturan yang tidak tertulis tidak termasuk dalam kriteria konstitusi. Pengertian seperti ini diakui oleh Sri Soemantri, menyamakan konstitusi dengan Undang-Undang Dasar sebagai aturan tertulis.

Di Belanda, istilah konstitusi tidak sama dengan Undang-Undang Dasar. UndangUndang Dasar dalam bahasa belanda disebut Gronwet. Dalam bahasa Indonesia, grond berarti dasar, sedangkan wet adalah Undang-Undang. Bagi L.J Van Apeldoorn UndangUndang Dasar adalah bagian dari konstitusi yang sifatnya tertulis. Ia memberi perluasan makna konstitusi tidak hanya memuat peraturan tertulis, melainkan juga peraturan tidak tertulis. ${ }^{10}$ Sepertinya devinisi konstitusi yang dikemukakan Van Apeldoorn ini mengakomodir bentuk konstitusi yang dianut di negara-negara yang menggunakan hukum tidak tertulis sebagai konstitusi, seperti Inggris dan Israel.

Kendati demikian, substansi adri konstitusi tersebut dapat diketahui dari pengalaman praktek ketatanegaraan. Fakta ini dapat ditelusuri dari uraian yang dikemukakan Jimly Asshiddieqie, konstitusi Inggris adalah suatu bangunan aturan, adat istiadat, kebiasaan-kebiasaan yang menentukan susunan dan kekuasaan organ-organ negara dan mengatur hubungan diantara organ negara serta hubungan antara organ negara dengan warga negara. ${ }^{11}$

Terlepas dari adanya perbedaan bentuk konstitusi apakah aturan tertulis atau tidak tertulis, setidaknya kriteria dari sebuah konstitusi yang adalah aturan atau ajaran dasar yang sudah disepakati oleh rakyat mengatur hak-hak warga negara, bentuk dan sisitem pemerintahan beserta lembaga yang menjalankan sekaligus melindungi hak-hak dasar warga negara. Aturan dasar ini dalam konteks Indonesia dituangkan dalam UndangUndang Dasar 1945 sebagai undang-undang tertinggi yang berlaku di Indonesia. Dengan demikian, kriteria konstitusi yang dimaksud disini berpedoman pada kriteria konstitusi dalam bentuk tertulis. Kriteria ini digunakan sesuai dengan sistem ketatanegaraan yang dianut dalam sebuah negara.

\section{Hukum Islam Sebagai Subsistem Hukun Nasional}

Indonesia sebagai negara bangsa memiliki konstitusi yang mengatur ajaran universal sebagaimana terdapat dalam UUD 1945. Dalam UUD ini ditegaskan bentuk negara Indonesia adalah negara hukum yang menjamin perlundungan hak dan kepentingan warga negaranya dalam menjalankan hukum dirumuskan dalam sebuah dasar negara yaitu Pancasila yang secara konstitusional disebut sebagai negara

\footnotetext{
${ }^{9}$ Dikutip dari Dahlan Thaib, dkk., Teori dan Hukum Konstitusi..., 8.

10 Pendapat Van Apeldoorn dikutip dalam Sri Soemantri, Prosedur dan Sistem Perubahan Konstitusi, (Bandung: Alumni, 1987), 1; Dahlan Thaib, dkk., Teori Hukum Konsttusi..., 6-8.

11 Jimly Asshiddieqie, Konstitusi dan Konstitusionalisme Indonesia, (Jakarta: Sinar Grafika, 2010), 16-17.
} 
pancasila. $^{12}$ Pancasila sebagai sumber hukm digali dari nilai-nilai luhur bangsa Indonesia yang bertujuan untuk mengatur prinsip-prinsip dasar kehidupan warga negara tanpa membedakan suku, ras, budaya dan agama.

Nilai-nilai luhur itu berasal dari keragaman suku, budaya dan agama yang mengatur kepentingan publik yang selanjutnya dirumuskan dalan sistem hukun nasioanal. Hukun Islam sebagi salah satu hukum yang berasal dari salah satu agama di Indonesia turut memainkan peran penting dalam pembangunan sistem hukum nasional dengan menjadikan nilai- nilai ajaran Islam sebagi bagian dari sistem hukum nasional. Usaha ini bukan menjadikan Islam sebagai konstitusi negara Pancasila dikarenakan Indonesia sebagai bangsa dan negara modern mewarisi nilai-nilai fundamental filososfis yang ditegakkan atas dasar normatif konstitusioal, yakni UUD 1945. Nilai- nilai fundamental dimaksud terutama filsafat hidup (Weltanschauung) bangsa (filsafat pancasila) serdasarkan suatu keinginan luhur bangsa untuk hidup bebas dan tertib menuju kesejahteraan. ${ }^{13}$

Amanat filosofis dan konstitusional demikian bersifat imperatif (mengikat, memaksa) semua yang ada didalam wilayah kekuasaan (kedaulatan) huku Indonesia untuk setia, menegakkan, mengamalkan, membudayakan, mewariskan dan melestarikan; termasuk kewajiban bela negara. Jadi, tidak ada seorang warga negara, bahkan lembaga-lembaga negara dan produknya, bahkan juga pejabat dan pemimpin negara yang tidak terikat (untuk setia) kepada amanat filosofis dan konstitusional sejak Indonesia merdeka dan untuk selamanya.

Pancasila sebagai sumber hukum utama bagi seluruh masyarakat Indonesia berorientasi pada memberikan rasa keadilan dan kesadaran hukum masyarakat sesuia dengan falsafah hidup dan kepribadian bangsa Indonesia. Aturan umum yang dibuat dan dirumuskan haruslah selalu mengacu dan tunduk pada prinsip dasar yang terkandung dalam pancasila yang berorientasi pada upaya melindungi masyarakat Indonesia dan menjamin keadilan sosial. Sesuai dengan prinsip umum diatas, pancasila sebagai sumber hukum nasional melahirkan kaedah-kaedah atau batasan-batasan untuk dipedomani dalam rangka pengembangan dan pembangunan hukum nasional. ${ }^{14}$

Pertama, hukum yang dibuat diarahkan pada integrasi bangsa baik secara teritorial maupun secara ideologis. Kaedah ini berasal dari rumusan yang terdapat dalam UUD 1945 yaitu "melindungi segenap bangsa Indonesia dan seluruh tumpah darah Indonesia". Kedua, hukum yang dibangun harus sejalan dengan prinsip demokrasi dan monokrasi melalui prosedur dan mekanisme; transparan, yang akuntabel sesuai dengan dasar-dasar falsafah hukum. Ketiga, hukum yang dirumuskan harus menjamin rasa keadilan sosial dalam arti memberi perlindungan kepada masyarakat "lemah" dalam menghadapi masyarakat "berkuasa". Keempat, menjamin kebebasan beragama yang menjunjung tinggi nilai-nilai toleransi beragama. Negara menjamin kebebasan dalam

\footnotetext{
${ }^{12}$ Moh. Mahfud MD, Membangun Politik HUkum, Menegakkan Konstitusi, Cet. III, (Jakarta: Raja Grafindo Persada, 2012), 281.

${ }^{13}$ Padmo Wahjono, "Asas Negara Hukum dan Perwujudannya dalam Sisitem Hukum Nasional", dalam M. Busyro Muqoddas, dkk (peyn.), Politik Pembangunan Hukum Nasional, (Yogyakarta: UII Pers, 1992), 43.

${ }^{14}$ Moh. Mahfud MD, Pedoman Hukum Tata Negara Pasca Amandemen Konstitusi, (Jakarta: LP3ES, 2007), 8 .
} 
arti melindungi kebebasan beragama setiap masyarakat yang diatur dalam perundangundangan, bukan memberlakukan hukum agama tertentu. ${ }^{15}$

Kebebasan beragama dalam negara hukum Pancasila bermakna positif, yaitu, adanya jaminan terhada kebebasan menjalankan perintah agama, dan perlindungan bagi warga negara yang menjalankan agamanya. Kebebasan bukan dimaksudkan seperti kebebasan di Amerika yaitu embiarkan paham ateis dan propaganda anti agama. ${ }^{16}$

\section{Hukum Islam: Dari Norma Agama Menjadi Norma Hukum}

Ajaran Islam yang diturunkan Allah kepada umat manusia tidak saja ditujukan kepada umat Islam saja, tetapi dapat berguna dan memberi nilai manfaat bagi seluruh umat manusia. Hal ini terlihat dari adanya ajaran universal (rahmatan lil 'alamin) yang dapat dikatakan sebagai bagian dari cita-cita utama hukum Islam. Cita-cita hukum ini dalam disiplin filsafat hukum Islam dikenal dengan prinsip maslahat, yaitu sebuah prinsip atau ajaran berorientasi pada nilai manfaat untuk kepentingan umat manusia yang berbasis pada pembangunan. ${ }^{17}$

Ajaran universal tersebut seperti ajaran tentang keadilan (Q.S an-Nisa': 135), musyawarah (Q.S. al-Syuara: 38), pengakuan dan perlindungan HAM (Q.S. al-Isra': 70), persamaan di hadapan hukum (Q.S al-Hujurat: 13), perdamaian (Q.S. al-Baqarah: 208), toleransi (Q.S. al-Baqarah: 217), amanah (Q.S. an-Nisa': 58), kesejahteraan (Q.S. al-Ma'arij: 24-24). ${ }^{18}$ Ajaran-ajaran ini merupakan ajaran dasar atau ajaran pokok yang harus ada dalam sebuah dasar pemerintahan atau konstitusi. Prinsip-prinsip dasar ini masih bersifat normatif sebagai norma agama atau moral, bukan sebagai norma hukum positif yang memiliki sangsi. Untuk itu, dibutuhkan peralihan norma agama ke norma hukum dengan cara merumuskan kembali asas-asas umum berdasarkan teori dan kaedah-kaedah fikih. Hasil rumusan ini disebut norma tengah (norma antara) sebagai pengambung norma agama dengan norma hukum konkrit. Sebagai contoh prinsip keadilan dalam kewarisan Islam. ${ }^{19}$

Langkah selanjutnya adalah menghubungkan norma antara tersebut kedalam norma hukum konkrit sebagaimana terdapat dalam perundang-undangan. Perubahan norma agama menjadi norma hukum diiringi dengan adanya sanksi hukum yang terdapat dalam norma hukum positif. Hal ini diperlukan guna aturan hukum yang diperbuat bersifat mengikat semua warga negara dan juga memperoleh ketegasan dalam perundang-undangan.

\section{E. Negosiasi Politik: Strategi Menuju Konstitusionalisasi Hukum Islam}

${ }^{15}$ Muhammadun dkk. Aktualisasi Hukum Islam di dalam Masyarakat yang Plural, Kumpulan Makalah sebagai Bahan kuliah pada Program Doktor Konsentrasi Ilmu Hukum dan Pranata Sosial Islam UIN Sunan Kalijaga Yogyakarta, 2016, 54.

${ }^{16}$ Muhammad Tahir Azhary, Negara Hukum: Suatu Studi Tentang Prinsip-Prinsipnya dilihat dari Segi Hukum Islam, Implementasinya pada Periode Negara Madinah dan Masa Kini, Cet. IV, (Jakarta: Kencana, 2010), 93.

${ }^{17}$ Konsep Maslahat atau Maqosid yang lebih komprehensif tergolong baru yaitu kemaslahatan didasarkan pada pengembangan SDM diadopsi dari Laporan Pembangunan PBB bersifat komprehensif. Jasser Auda, Membumikan Hukum Islam Melalui Maqosid Syariah: Pemdekatan Sistem, terj. Rosidin dan Ali Abd el-Mun'im, (Bandung: Mizan, 2015), 60.

${ }^{18}$ Juhaya S. Praja, Filsafat Hukum Islam, (Bandung: Pusat Penerbitan UNISBA, 1995), 67-77.

${ }^{19}$ Syamsul Anwar, Hukum Perjanjian Syariah: Studi tentang Teori Akad dalam Fikih Muamalat, (Jakarta: Raja Grafindo Persada, 2007), 12-15. 
Usaha menerapkan Islam sebagai norma hukum yang diakui dalam perundangundangan Indonesia memberi nuansa baru bagi perjuangan umat Islam Indonesia sebagai masyarakat muslim mayoritas. Keinginan menjadikan Islam sebagai dasar negara Indonesia saat ini menjadi sesuatu yang mustahil mengingat perdebatan tentang ideologi negara telah "selesai" di era awal kemerdekaan. ${ }^{20}$ Disamping bentuk negara adalah negara pancasila yang menganut keanekaragaman sistem budaya, ras dan agama juga keberpihakan umat Islam Indonesia memilih cara yang berbeda-beda. Konsensus dari keragaman tersebut adalah berlakunya tiga sistem hukum yang dianut oleh masyarakat Indonesia sesuai dengan penggolongan rakyat Indonesia. Tiga sistem hukum tersebut adalah sistem hukum Islam, hukum adat, dan hukum barat. Sebagai bentuk kompromi dari tiga sistem hukum yang berlaku di Indonesia, A. Qodry Azizi menawarkan dengan cara memadukan ketiga sisitem hukum yang berlaku di Indonesia, yaitu hukum Islam, hukum adat, dan hukum barat. ${ }^{21}$ Moh. Mahfud MD, menawarkan pendekata politik hukum yang dapat dijadikan sebagai solusi alternatif bagi umat Islam yang ingin menerapkan ajaran Islam di Indonesia. ${ }^{22}$

Moh. Mahfud MD memberikan argumen pentingnya umat Islam berpartisipasi dalam menyampaikan ide atau aspirasi melalui sisitem perpolitikan di Indonesia sesuai dengan ajran islam yang mengajarkan umatnya berpolitik. Pertama, umat Islam hidup di dalam sebuah organisasi atau sistem pemerintahan sebagai wadah untuk menyampaikan hak dan keyakinannya selaku warga negara. Kedua, Islam sebagai agama yang kaffah mengatur kehidupan umat tidak terbatas pada persoalan ibadah mahdhah saja, tetapi juga ibadah ghairu mahdhah (muamalah dalam arti luas) mencakup semua aspek kehidupan, termasuk aspek politik. Ketiga, Islam adalah agama yang universal memerintahkan umatnya agar amar ma'ruf dan nahi munkar yang dapat memberi manfaat atau kemaslahatan bagi seluruh alam. (rahmatan lil alamin). ${ }^{23}$

Ketiga argumen yang dikemukakan oleh Moh. Mahfud MD di atas setidaknya dapat memberikan gambaran bahwa keinginan menerapkan ajaran Islam melalui pendekatan politik mengarahkan pada upaya pribumisasi ajaran Islam. Cikal bakal lahirnya pendekatan politik yang diperutukan bagi umat Islam adalah perintah agama islam melaksanakan amar ma'ruf nahi munkar. Menurut Fazlur Rahman, ideology amar ma'ruf nahi munkar ini bertujuan untuk menciptakan masyarakat yang adil. ${ }^{24}$ Perintah ini membetuk kewajiban moral bagi umat Islam yang diagunakan sebagai pengikat tanggungjawab bersama. ${ }^{25}$ Atas dasar inilah munculnya pandangan berbeda dalam

${ }^{20}$ Polemik tentang ideologi negara menjadi perdebatan yang serius dikalangan umat Islam Indonesia. Tokoh sentral nasionalis Islam yang mewakili perjuangan umat islam menjadikan islam sebagai dasar negara adalah Mohammad Nasir. Sedangkan dikalangan nasionalis sekuler diwakili oleh Soekarno yang berpandangan bahwa bentuk negara Indonesia tidak mesti negara Islam, tetapi negara kebangsaan yang mengatur semua ajaran agama. Perdebatan ini berpihak pada kalangan nasionalis sekuler yang mengusung bentuk negara kebangsaan yang selanjutnya melahirkan sebuah konstitusi negara yaitu UUD 1945. Endang Saefuddin Anshari, Piagam Jakarta 22 Juni 1945: Sebuah Konsensus Nasional tentang Dasar Negara Republik Indonesia(1945-1949), (Jakarta: Gema Insani Press, 1997), 910 .

${ }^{21}$ A. Qodry Azizi, Hukum Nasional: Elektisisme Hukum Islam dan Hukum Umum, (Bandung: Teraju Mizan, 2004), 8; Moh. Mahfud MD, Membangun Politik Hukum ..., 288.

${ }^{22}$ Moh. Mahfud MD, Membangun Politik Hukum..., 284.

${ }^{23}$ Moh. Mahfud MD, Membangun Politik Hukum..., 284.

${ }^{24}$ Fazlur Rahman, Tema-tema Pokok al-Qur'an, (Bandung: Pustaka, 1984), 36.

25 David Little, dkk., Kebebasan Aagama dan Hak-hak Asasi Manusia: Kajian Lintas Kultural Islam-Barat, terj. Riyanto, (Yogyakarta: Pustaka Pelajar, 2007), 107. 
memahami substansi dari memahami perintah menegakkan amar ma'ruf nahi munkar di kalangan umat Islam, khususnya umat Islam Indonesia.

Disatu pihak, upaya menegakkan amar ma'ruf nahi munkar dipahami perlu adanya sebuah kekuasaan dengan tujuan pelaksanaan amar ma'ruf nahi munkar dapat terlaksana dengan baik. Konsekuensi dari pandangan ini adalah kehadiran negara sebagai simbol kekuasaan dirasa butuh sebagai landasan formal mereka dalam menegakkan perintah agama. Sedangkan pihak lain, umat Islam memahami pelaksanaan amar ma'ruf nahi munkar bukan dengan kekuasaan negara yang identik formalistik, tetapi lebih kepada semangat nilai-nilai substansi yang terdapat dalam amar ma'ruf nahi munkar. Nilai-nilai tersebut menekankan pada ajaran universal (rahmatan lil alamin). ${ }^{26}$

Dalam prakteknya, upaya ini menampilkan dua model penerapan, yaitu model penerapan yang bersifat formal dan model penerapan yang bersifat substantif. Pertama, pendekatan politik bersifat formal-struktural. Moh. Mahfud MD dalam bukunya Membangun Politik Hukum, Menegakkan Konstitusi berpendapat bahwa perjuangan umat Islam melalui pendekatan politik formalistik-struktural ini lebih mengarah pada upaya menegakkan negara Islam sekaligus Undang-Undang Dasar sebagai konstitusi resmi dari negara Islam. Keberadaan negara Islam dijadikan legitimasi sebagai syarat pelaksanaan amar ma'ruf nahi munkar. ${ }^{27}$ Kedua, pendekatan politik bersifat substantifkultural adalah upaya internalisasi nilai-nilai keislaman menjadi norma hukum tertulis dalam sejumlah peraturan perundang-undangan dalam sistem hukum Indonesia. Aspek kultural menekankan penanaman dan penyebaran nilai-nilai substantif ajaran Islam tanpa harus membungkus dengan simbol formal Islam. ${ }^{28}$

Di era reformasi, keinginan menerapkan ajaran substansi kedalam sistem hukum Indonesia khususnya umat Islam dilakukan melalui sebuah organisasi politik, ormas keagamaan, penguatan akademis dan sejumlah regulasi yang secara legal-formal menerapkan yang kesemuanya masih berada dalam sistem hukum Indonesia. Sedangkan pendekatan kultural mengedapankan nilai-nilai pokok yang terdapat dalam ajaran Islam itu sendiri. Dalampendekatan kultural ini memberi peluang lebih luas menerapkan nilainilai ajaran Islam yang bersifat privat maupun bersifat publik.

Penerapan hukum Islam dengan pendekatan kultural menjadilebih bermakna jika dalam rumusan perundang-undangan memuat nilai-nilai substansi ajaran Islam yang secara normatif-kultural ajaran agama yang diyakininya terpantul dalam sikap keseharian masyarakat muslim Indonesia. Nilai-nilai substansi ajaran Islam ini bisa saja mencakup hukum privat (hukum yang bersifat diyani) dan hukum public (bersifat qadha'i). ${ }^{29}$ kedua dimensi hukum ini yang diambil atau dimasukan kedalam sistem hukum nasional adalah nilai-nilai substansinya saja.

Hukum Islam yang ingin diterapkan dalam sistem hukum nasional cakupannya menjadi lebih luas, tidak hanya terbatas pada satu aspek saja yaitu aspek privat. Namun demikian persoalan-persoalan yang menyangkut kepentingan individu jika diatur dalam perundang-undangan tentunya dapat mengekang kebebasan individu dan memberatkan masyarakat. ${ }^{30}$ Seperti persoalan ibadat formal seperti shalat dan puasa, masalah akhlak

${ }^{26}$ David Little, dkk., Kebebasan Aagama..., 284

${ }^{27}$ David Little, dkk., Kebebasan Aagama..., 286.

${ }^{28}$ David Little, dkk., Kebebasan Aagama..., 268.

${ }^{29}$ Rifyal Ka'bah, Hukum Islam Di Indonesia: Perspektif Muhammadiyah Dan NU, (Jakarta: Universitas Yasri, 1999), 56-59.

${ }^{30}$ Salah satu hak kebebasan menjadi terbatas bagi individu lain seperti hak kebebasan beragama. Rohidin, Konstruksi Baru Kebebasan Beragama: Menghadirkan Nilai kemanusiaan yang Adil dan Beradab di Negara Hukum Indonesia, (Yogyakarta: UII Press, 2015), 43; David Little, dkk., Kebebasan 
seperti aturan tegur sapa di tempat umum, cara memasuki tempat umum, tata cara bertamu, demikian pula masalah keyakinan tidak memaksakan kehendak, dan persoalan pribadi lainnya tidak perlu diatur oleh negara (undang-undang).

Aspek individu dalam Islam baru dapat diatur oleh negara apabila persoalan ibadat, akhlak dan keyakinan pribadi sudah menyangkut hak dan kewajiban orang lain. Misalnya maslah zakat dan haji perlu diatur oleh undang-undang karena keduanya menyangkut pengelolaan dana masyarakat; menyangkut kelebihan dana; pengumpulan dana; distribusi dana zakat kepada yang berhak (mustahik) dan persoalan-persoalan lainnya yang dapat menimbulkan masalah hukum.

Sedangkan aspek hukum yang mengatur kepentingan publik seperti masalah pidana, perbankan, perdagangan, wakaf, kesehatan, hubungan antar warga negara dan antar negara, dan persoalan-persoalan publik membutuhkan penguasa, agar dalam pelaksanaannya mempunyai kekuatan hukum mengikat. Tanpa adanya aturan pelaksana dalam perundang-undangan akan terjadi kesulitab dan bahkan kurang mendapat peghormatan yang layak dan efektif dalam masyarakat.

Jika ditinjau dari sisi kewenangan atau pembagian tugas, tanpa bermaksud memisahkan keuasaan agama dari kekuasaan negara, persoalan hukum yang menyangkut individu (hukum yang bersifat diyani) menjadi kewenangan Majelis Ulama Indonesia (MUI) dalam menjalankan tugasnya secara profesional. Demikian pula dengan persoalan yang menyangkut kepentingan public merupakan kewenangan pemerintah -dalam hal ini- lembaga peradilan memutuskan perkara berdasarkan peraturan perundang-undangan yang berlaku. Dengan kata lain, untuk saat ini persoalan yang dianggap menjadi aspek individu (diyani) bisa saja pada suatu saat nanti akan menjadi persoalan publik yang membutuhkan campur tangan penguasa (bersifat qadha'i). seperti persoalan murtad yang semula adalah wilayah privasi, bisa saja persoalan murtad akan menjadi wilayah publik jika sampai mengganggu stabilitas negara (pemerintah).

\section{F. Penutup}

Konstitusionalisasi hukum Islam kedalam sisitem hukum nasional hanya dapat dilakukan melalui pendekatan politik hukum yang bersifat substansi, bukan formalistik. Penerapan hukum Islam secara substansi sangat terbuka peluang untuk memasukan nilai-nilai universal dari ajaran Islam. Pendekatan ini mempertegas bahwa secara tidak langsung ajaran-ajaran Islam universal seperti perlindungan terhadap hak-hak asasi manusia telah tercantum dalam konstitusi negara Indonesia, walaupun tidak menggunakaan bahasa agama. Turunan dari hak-hak asasi tersebut dapat dilakukan pada level perundang-undangan seprti Undang-Undang Perkawinan, Peradilan Agama. Sementara keinginan untuk menjadikan Indonesia sebagai negara Islam tidak mendapat pengakuan di dalam konstitusi, mengingat negara Indonesia bukanlah negara Islam, melainkan negara hukum berdasarkan pancasila senantiasa mengakomodir keragaman sistem nilai budaya, ras dan agama seluruh masyarakat Indonesia.

Peluang menerapkan hukum Islam sebagaimana diamanahkan dalam UUD 1945 dapat dilakukan pada tingkat perundang-undangan atau instruksi presiden. Pada tingkat ini, upaya memasukan nilai-nilai ajaraan Islam terlihat lebih mudah diterima dari pada tingkat konstitusi.

Agama dan Hak-Hak Asasi Manusia: Kajian Lintas Kultural Islam-Barat, terj. Riyanto, (Yogyakarta: Pustaka Pelajar, 2007), 112. 


\section{DAFTAR KEPUSTAKAAN}

Abubakar, Al-Yasa. Penerapan Syari'at Islam di Aceh: Upaya Penyusunan Fikih dalam Negara Bangsa, Banda Aceh: Dinas Syari'at Islam Aceh, 2008.

Anshari, Endag Saifuddin. Piagam Jakarta 22 Juni 1945: Sebuah Konsensus Nasional tentang Dasar Negara Republik Indonesia (1945-1949), Jakarta: Gema Insani Press, 1997.

Anwar, Syamsul. Hukum Perjanjian Syariah: studi Tentang Teori Akad dalam Fikih Muamalat, Jakarta: Raja Grafindo Persada, 2007.

Asshiddiqie, Jimly. Konstitusi dan Konstitusionalisme Indonesia, Jakarta: Sinar Grafika, 2010.

Auda, Jesser. Membumikan Hukum Islam Malalui Maqasid Syariah: Pendekatan Sistem, terj, Rosidin dan Ali Abd el-Mun'im, Bandung: Mizan, 2015.

Azhari, Muhammad Tahir. Negara Hukum: Suatu Studi tentang Prinsip-Prinsipnya Dilihat dari Segi Hukum Islam, Implementasinya pada Periode Negara Madinah dan Masa Kini, Cet. IV, Jakarta: Kencana, 2010.

Azizy, A. Qodri. Hukum Nasional: Eklektisisme Hukum Islam dan Hukum Umum, Bandung: Teraju Mizan, 2004.

Fauzi, Moh. Legislasi Pelaksanaan Syari'at Islam di Provinsi Nanggroe Aceh Darussalam: Pergumulan Sosio-Politik dan Tinjauan Hukum Tata Negara, Disertasi Pascasarjana IAIN Ar-Raniry Banda Aceh, 2009.

Ka'bah, Rifyal. Hukum Islam di Indonesia: Perspektif Muhammadiyah dan NU, Jakarta: Universitas Yasri, 1999.

Little, David. dkk., Kebebasan Agama dan Hak-Hak Asasi Manusia: Kajian Lintas Kultural Islam-Barat, terj, Riyanto, Yogyakarta: Pustaka Pelajar, 2007.

Ma'arif, Ahmad Syafi'I. Islam dan Masalah Kenegaraan: Studi Tentang Pencaturan dalam Konstituante, Jakarta: LP3ES, 1985.

MD, Moh. Mahfud, Membangun Politik Hukum, Menegakkan Konstitusi, Cet. III, Jakarta: Raja Grafindo Persada, 2012. , Aktualisasi Hukum Islam didalam Masyarakat yang Plural, Kumpulan Makalah Sebagai Bahan Kuliah pada Program Doktor Konsentrasi Ilmu Hukum dan Pranata Sosial Islam UIN Sunan Kalijaga Yogyakarta, 2016. , Perdebatan Hukum Tata Negara Pasca Amandemen Konstitusi, Jakarta: LP3ES, 2007.

Praja, Juhaya S. Filsafat Hukum Islam, Bandung: Pusat Penerbitan UNISBA, 1995.

Prokodikoro, Wirjono. Asas-Asas Hukum Tata Negara di Indoensia, Jakarta: Dian Rakyat, 1989.

Rahman, Falur. Tema-Tema Pokok Al-Qur'an, Bandung: Pustaka, 1984.

Rohidin, Konstruksi Baru Kebebasan Beragama: Menghadirkan Nilai Kemanusiaan yang Adil dan Beradab di Negara Hukum Indonesia, Yogyakarta: UII Press, 2015.

Soemantri, Sri. Prosedur dan Sistem Perubahan Konstitusi, Bandung: Alumni, 1987.

Soepiadhi, Soetanto. Meredesain Konstitusi, t.tp: Kepel Press, 2004.

Thaib, Dahlan dkk., Teori dan Hukum Konstitusi, Cet. 9, Jakarta: Raja Grafindo Persada, 2011

Tim Penyusun Kamus, kamus Besar Bahasa Indonesia, Edisi III, Jakarta: Balai Pustaka, 1991. 
Wahjono, Padmo. “ Asas Negara Hukum dan Perwujudannya dalam Sistem Hukum Nasional", dalam M. Busyro Muqoddas, dkk (peyn), Politik Pembangunan Hukum Nasional, Yogyakarta: UII Press, 1992. 